\title{
Variation in movement behavior of alligators after a major hurricane
}

\author{
Bradley A. Strickland ${ }^{1 *}$ (D, Kirk Gastrich ${ }^{1}$, Frank J. Mazzotti ${ }^{2}$, Jordan A. Massie ${ }^{3}$, Valeria Paz ${ }^{1}$, Natasha Viadero ${ }^{3}$, \\ Jennifer S. Rehage ${ }^{3}$ and Michael R. Heithaus ${ }^{1}$
}

\begin{abstract}
Background: Hurricanes can have catastrophic effects on coastal ecosystems. To minimize negative impacts of storms, animals may seek shelter in place, move to a nearby refuge, or evacuate long-distances. Crocodilians can be important predators in estuarine habitats, but little is known about how they respond to extreme weather events. We investigated the movement behaviors of eight acoustically tracked American alligators (Alligator mississippiensis) before, during, and after Hurricane Irma in 2017 within the Shark River Estuary of Everglades National Park, USA. Using tracking data, we compared their movements and habitat use before and after the hurricane to similar timeframes in other years without major storms.
\end{abstract}

Results: We observed considerable variation in movement tactics and responses to the hurricane. Of eight animals that we tracked, two showed no changes in movement or habitat use throughout the study. Two animals ceased upstream excursions that they were regularly making before the hurricane with one of these animals reducing the distance ranged across the river system. Another animal moved upstream from the lower river to the mid-estuary immediately after the hurricane despite having not done this in the 60 days prior. Two other animals moved from the marsh and mangrove forest habitats to river channels several days after the hurricane. One animal shifted to commuting downstream from its upstream habitat shortly before the storm and continued this behavior for the rest of the 2017 and 2018 wet seasons.

Conclusions: We found considerable variability in behavioral responses to the hurricane, ranging from no discernable changes in movements to one animal exhibiting a complete shift in movement tactics not observed by any animal in the long-term tracking of this population. Our research provides insight into alligator movement behavior and ecology in the context of a major hurricane disturbance.

Keywords: Animal movement, Estuaries, Extreme events, Hurricane, American alligator, Alligator mississippiensis

\section{Background}

Tropical cyclones, including hurricanes, can cause rapid and devastating physical and ecological changes to coastal and estuarine ecosystems. These disturbances can damage physical structures, impact hydrological conditions, alter biogeochemical processes, and directly affect

*Correspondence: bstri007@fiu.edu

${ }^{1}$ Department of Biological Sciences, Florida International University, Miami, FL 33199, USA

Full list of author information is available at the end of the article organisms [27, 31]. Extreme precipitation, high winds, and oceanic storm surge are often associated with hurricanes. In consequence, many coastal riverine environments experience increased water discharge, increased turbidity, modified salinity regimes, and altered delivery of nutrients and sediment [27].

In response to hurricanes and changing environmental conditions, animals may seek shelter in place, evacuate the area, or in some cases may die. Altered movements, distribution, and abundance of animals as a result of extreme events are well-documented [1]. In addition, 
some animals use cues such as declining barometric pressure or changes in hydrology to know when to evacuate or respond before an extreme weather event $[1,24$, $36,37]$.

American alligators (Alligator mississippiensis) are abundant large-bodied predators and occur in nearly every type of fresh and brackish water habitat across the southeastern United States [25]. The ecology of alligators residing in estuaries is well-studied, including their movement behavior in the coastal Everglades [15, 33, 34]. Given that coastal areas are subject to hurricanes, tropical storms, and other extreme weather events, alligators certainly experience impacts of these major disturbances. In the earliest account, Chabreck [7] observed that alligators were swept inland more than $16 \mathrm{~km}$ by Hurricane Audrey in 1957. Elsey and Aldrich [13] found a live juvenile alligator on a Louisiana beach after Hurricane Ike (2008) almost $500 \mathrm{~km}$ from its tagging site 8 weeks earlier. Another study suspected that storm surge in southwestern Louisiana after Hurricane Rita in 2005 pushed alligators inland [22]. These reports indicate that coastal alligators may be passively displaced by changing hydrology from major storms; however, no studies have revealed the direct movement responses of crocodilians to tropical cyclones $[8,13]$.

Herein, we investigated the movement behaviors of acoustically tracked alligators before, during, and after Hurricane Irma, which passed over Shark River Estuary of Everglades National Park, USA, in September 2017. Other predators tracked within the estuary include juvenile bull sharks [36] and common snook [24], which showed varying responses to Hurricane Irma, including sheltering in place, early evacuations, and apparent mortality.

\section{Methods}

\section{Study area and hurricane}

The Shark River Estuary of Everglades National Park, USA (Fig. 1) is one of the primary systems for freshwater from the Everglades to flow into the Gulf of Mexico [35]. Starting at the Gulf of Mexico, the braided tidal waterway is bordered by predominantly red mangroves (Rhizophora mangle) until nearly $30 \mathrm{~km}$ upstream where it transitions into freshwater marsh [9]. The lower river (first $15 \mathrm{~km}$ from the river mouth) has deep (3-5 m) and wide $(100 \mathrm{~m})$ riverine channels and is heavily marineinfluenced $[9,24]$. The mid-estuary $(15-23 \mathrm{~km}$ from the river mouth) is characterized by Tarpon Bay, a shallow $(<2 \mathrm{~m})$, open (200-500 m across) bay habitat [24]. Rookery Branch, or the upper portion of Shark River (above $23 \mathrm{~km}$ from the river mouth), receives limited tidal fluctuations and is characterized by low-salinity, narrow creek channels $(2-50 \mathrm{~m})$ bordered by both mangrove and freshwater sawgrass marshes (Cladium sp.) [9, 24). Greater rainfall during the wet season (May-October) leads to lower salinity in the estuary relative to the dry season (November-April) [32, 33]. The estuary has greater productivity in the lower river and is limited by marine phosphorous input [9].

Hurricane Irma, in September 2017, caused widespread and catastrophic damage in the northeastern Caribbean and the Florida Keys [5]. Irma, as a Category 4 hurricane (Saffir-Simpson Hurricane Scale), was reported to be about $60 \mathrm{~km}$ from the Shark River mainstem at 15:00 UTC 10 September 2017, hereafter referred to as "strike". The hurricane brought high winds, high rainfall, and storm surge across the study area. Barometric pressure began to decline, and river stage began to drop from reverse storm surge on the morning of 9 September [24]. The Shark River experienced an estimated $67 \mathrm{~h}$ of rapid changes in pressure and river conditions between 5:00 UTC on 9 September until 00:00 UTC on 12 September, (see [24]).

\section{Field methods}

A team of trained handlers captured alligators in MarchNovember 2016 using a pole and snare technique from an airboat or prop driven boat. High-powered spotlights were used at night to find alligators by looking for reflective eyeshine and then slowly approaching the targeted animal. For each captured alligator, we recorded gender from cloaca examination [6]. We measured total length, tail girth, head length, and snout-vent length to the nearest $\mathrm{cm}$. In addition, we recorded weight to the nearest $\mathrm{kg}$ using a spring scale.

We attached an acoustic transmitter (V16-4x-069, Vemco, Halifax, NS, Canada) to the tail base of each animal $(n=15)$ following the attachment procedure of Rosenblatt and Heithaus [33]. Pulse rates were set at a random interval between 60 and $120 \mathrm{~s}$ resulting in an estimated battery life of 1825 days. After attachment, animals were subsequently released at their capture locations. We tracked animals within an array of 37 "gated" receivers (VR2W, Vemco, Halifax, NS, Canada) that allow us to determine the direction of movement and movements into and out of major areas within the estuary (see Rosenblatt and Heithaus [33] for more detail; Fig. 1). We secured the receivers to a PVC pipe set in concrete and deployed the entire unit underwater. Every 3 to 5 months, we downloaded the data and replaced batteries. Mean detection ranges of receivers were approximately $500 \mathrm{~m}$ (see [33]), though detectability likely decreased with increased acoustic noise associated with wind and storm surge caused by the hurricane. All receivers with the exception of seven coastal receivers near the river mouth remained deployed throughout the hurricane. These 


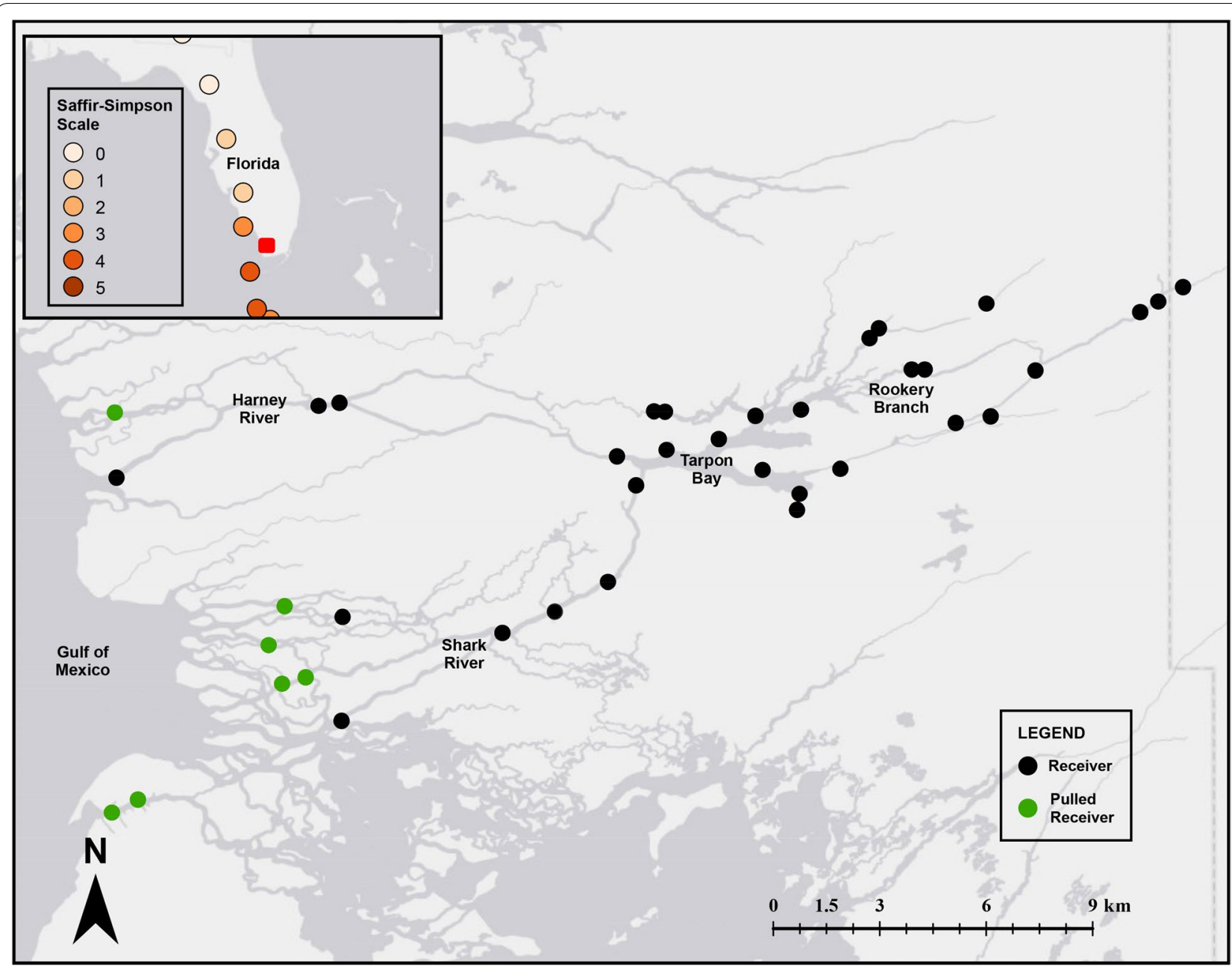

Fig. 1 Configuration of an acoustic array in the Shark River Estuary, Florida, USA. Black and green dots denote one of 37 receivers. Black dots indicate that a receiver was deployed throughout the entire study period whereas green dots show receivers that were pulled just before the hurricane and redeployed just after due to their vulnerability. The inset in the upper left corner displays the state of Florida with the study site as a red rectangle. The track of Hurricane Irma and its intensity is also presented in the inset as it was at its closest (about 60 km) to the Shark River mainstem at 15:00 UTC 10 September 2017 (see Strickland et al. [36])

seven receivers were removed on 6 September 2017 and returned on 2 October 2017. The removed receivers did not affect our inference of movements across broad habitats within the estuary.

\section{Analysis}

We estimated Fulton's body condition factor $(K)$ using weight $(M)$ and snout-vent length (SVL) as $K=M / \mathrm{SVL}^{3}$ $\times 10^{5}$ [3]. Alligators were considered as being in poor $(K \leq 1.95)$, fair $(1.95<K \leq 2.10)$, good $(2.10<K \leq 2.27)$, or excellent condition $(K>2.27)[3,26)$. We used Pearson's product moment to test the correlation between body condition and total length.

We used Fisher's exact test to determine if categorical behavioral response depended on body condition.
Behavioral groupings were classified as no change and possible change in movements or habitat use as a result of the hurricane based on pre-hurricane movement tactics. Given our small sample sizes, we grouped body conditions: poor and fair vs. good and excellent.

We estimated mean river distance from the mouth daily for each alligator, except alligators $\times 54261, \times 54262$, and $\times 54263$, which were not included due to gaps of no detections before and during the storm for comparison. River distance is a proxy for general habitat use due to the gradient of salinity throughout the estuary (see description of study area for more detail). Analysis of changes in mean river distance allowed us to investigate potential shifts in broad-scale habitat use in the estuary as a result of the hurricane. We used mean daily distance from the 
60 days before the storm and 60 days after the storm, though we excluded 9-12 September that was identified by Massie et al. [24] as a window of rapidly changing environmental conditions (e.g., water level, water flow, barometric pressure, wind) at Shark River Estuary. However, we did also estimate mean river distance during the 4-day hurricane impact window. We did the analysis within 30-day timeframes as well. As "control" timeframes without a hurricane, we also estimated mean distances in the corresponding timeframe in 2016 and 2018 if the animal was detected for those periods. We analyzed each animal separately and used a two-sample $t$ test to compare mean river distance occupied by an animal before and after the storm as well as for the control timeframes. We compared both before and after using the 30-day shorter timeframe to the 4 days during the hurricane as well. We also estimated mean river distance within the entire 60-day and 30-day periods for each animal and used a paired two-sample $t$ test to investigate changes in habitat use of the population as a whole.

To understand movement patterns and if step length changed, we employed \pm 1 SD from mean river distance as a proxy for space use, hereafter "linear distance range", describing how much of the river length was used by an individual (see [36]). Like our analyses of river distance, we used two-sample $t$ tests to compare linear river distance ranges by individual and across years. We also used a paired $t$ test to determine if distance ranges before and after the hurricane changed at the population level. We did not compare these to the space used during the 4 days during hurricane window because of the short time frame.

We performed statistical analyses in $\mathrm{R}$ (Mac version 3.4.3; R Foundation for Statistical Computing; Vienna, Austria). We reported means with \pm 1 standard deviation (SD) and evaluated significance at $\alpha=0.05$.

\section{Results}

We tracked 15 animals from 2016 to 2019, but only eight animals had detections within the 30 days before or after the hurricane (Tables 1 and 2). Of these eight animals, only one was female. Total length averaged $220.2 \pm 32.0 \mathrm{~cm}$ and ranged from $171.1-264.9 \mathrm{~cm}$. Weight averaged $32.0 \pm 15.0 \mathrm{~kg}$ and ranged from 11.2 $58.0 \mathrm{~kg}$. Fulton's condition factor averaged $2.1 \pm 0.3$ and ranged from 1.9-2.6. Using Fulton's condition factor at time of capture, there were four animals in poor, three in good, and one in excellent body condition. Fulton's condition factor was not correlated with total length $\left(r=0.233, t_{6}=0.585, P=0.580\right)$, and exhibiting a possible behavioral response to the hurricane did not vary with body condition either $(P=1)$.

\begin{tabular}{|c|c|c|c|c|}
\hline Transmitter & $\begin{array}{l}\text { Number } \\
\text { of relocations }\end{array}$ & Days tracked & $\begin{array}{l}\text { Days } \\
\text { located } \\
(\%)\end{array}$ & $\begin{array}{l}\text { Hurricane } \\
\text { movement? }\end{array}$ \\
\hline 54252 & 78,312 & 965 & 66 & Yes \\
\hline 54253 & 17,941 & 771 & 39 & Yes \\
\hline 54254 & 27,382 & 792 & 48 & Yes \\
\hline 54255 & 76,459 & 621 & 79 & No \\
\hline 54260 & 27,987 & 991 & 51 & Yes \\
\hline 54261 & 4448 & 774 & 4 & Yes \\
\hline 54262 & 423,696 & 1033 & 57 & No \\
\hline 54263 & 1662 & 982 & 1 & Yes \\
\hline
\end{tabular}

Days located shows the percentage of days that the animal was located at least once over its tracking period (see Table 1; though calculations for days tracked in Table 2 started at first detection date not capture date). Hurricane movement describes whether an alligator exhibited some detectable change in movement or location within the estuary related to Hurricane Irma in 2017

Table 1 Capture and tracking information for acoustically tagged American alligators (Alligator mississippiensis) in the Shark River Estuary, Florida, USA

\begin{tabular}{llllll}
\hline Transmitter & Tracking dates & Sex & Total length $(\mathbf{c m})$ & Weight $(\mathbf{k g})$ & $\begin{array}{c}\text { Fulton's } \\
\text { condition }\end{array}$ \\
\hline 54252 & $03 / 17 / 16-01 / 07 / 19$ & M & 264.9 & 58.0 & 2.22 \\
54253 & $11 / 16 / 16-12 / 29 / 18$ & M & 207.4 & 25.9 & 2.16 \\
54254 & $11 / 07 / 16-01 / 09 / 19$ & M & 208.6 & 22.0 & 1.94 \\
54255 & $03 / 16 / 16-01 / 28 / 18$ & F & 198.1 & 32.0 & 1.87 \\
54260 & $04 / 26 / 16-01 / 13 / 19$ & M & 210.0 & 39.0 & 2.63 \\
54261 & $04 / 15 / 16-05 / 30 / 18$ & M & 250.1 & 45.5 & 1.90 \\
54262 & $03 / 16 / 16-01 / 14 / 19$ & M & 251.1 & 11.2 & 2.23 \\
\hline 4263 & $04 / 26 / 16-01 / 04 / 19$ & M & 171.1 & 1.91 \\
\hline
\end{tabular}

Tracking dates describe the capture date and the date of last detection using the latest acoustic receiver array download in January 2019 . Fulton's condition factor was calculated as $K$, a metric for body condition 
There were no population-level directional shifts in habitat use across the estuary before and after the hurricane on either timescale (30 days, $t_{4}=0.355, P=0.741$; 60 days, $\left.t_{4}=0.516, P=0.633\right)$ or for other control years (2016: 30 days, $t_{2}=0.526, P=0.651 ; 60$ days, $t_{2}=0.806$, $P=0.505$; 2018: 30 days, $t_{3}=1.168, P=0.327 ; 60$ days, $\left.t_{3}=0.335, P=0.760\right)$. Similarly, we saw no population-level changes in linear distance ranges (30 days, $t_{4}=2.225, P=0.090 ; 60$ days, $\left.t_{4}=1.455, P=0.219\right)$ or for other years (2016: 30 days, $t_{2}=-0.276, P=0.809$; 60 days, $t_{2}=-2.010, P=0.182 ; 2018: 30$ days, $t_{3}=0.044$, $P=0.967 ; 60$ days, $t_{3}=-0.203, P=0.852$ ). Though the direction of change for the population was not consistent, some animals appeared to be affected by the hurricane and others did not (Table 3 ).

Two animals exhibited no discernable differences in movement patterns or their use of macro-habitats within the estuary before, after, or during the storm (Fig. 2). Animal $\times 54255$ exhibited no change throughout the study and resided solely in Rookery Branch (upstream portion of Shark River Estuary) with regular detections at two receivers until February 2018. Alligator $\times 52455$ did not change river distance before or after the hurricane (data were constant for 30- and 60-day analyses). They were also constant in the 4-day hurricane window. They did not differ in 2016 either (30 days, $t_{56.7}=-0.431$, $P=0.669 ; 60$ days, $\left.t_{114.9}=-0.490, P=0.625\right)$. Similarly, linear distance ranges were essentially constant before and after the hurricane for both 30- and 60-day analyses and did not differ in 2016 (30 days, $t_{53.8}=-0.870$, $P=0.388 ; 60$ days, $\left.t_{103.6}=-0.910, P=0.365\right)$. Animal $\times 54262$ had regular detections, with a few gaps lasting more than a month at our most upstream receivers in
Rookery Branch for almost a year and a half. However, there was a nearly a 6-month gap beginning immediately before the hurricane until the animal began to be regularly detected at the same receiver. This long gap prohibited statistical comparisons in movement and space use.

Animal $\times 54252$ was detected at least once nearly every day starting 2 months after its capture to the last receiver download in January 2019. The animal was detected exclusively in upstream Rookery Branch habitats. It spent most of its time near one receiver station at $24 \mathrm{~km}$ upstream and made six trips 1 to $2 \mathrm{~km}$ upstream from August 2016 to August 2017. No upstream trips were detected after the hurricane and the animal has only been detected at the 24- $\mathrm{km}$ station since the last download in January 2019. Alligator $\times 52452$ 's mean river distances were not different before and after the hurricane (30 days, data were constant; 60 days, $t_{43}=1.000, P=0.322$ ). Mean river distances across the 30 days before, after, and the 4 days during were constant. There were no differences in the same timeframe in 2016 (30 days, $t_{28}=-1.000$, $P=0.326$; 60 days, $\left.t_{71.5}=-0.439, P=0.662\right)$ and in 2018 (data were constant for 30 - and 60-day analyses). Linear distance ranges were not different before and after the hurricane (30 days, data were constant; 60 days, $\left.t_{43}=1.000, P=0.322\right)$. Distance ranges were not different for 2016 (30 days, data were constant; 60 days, $t_{36}=1.602$, $P=0.118$ ) or 2018 (data were constant for 30- and 60-day analyses) either.

Animal $\times 54253$ was detected in both the lower Shark River ( $85 \%$ of hourly detections) and Tarpon Bay (15\%; mid-estuary bay) from its capture in November 2016 to the last download in January 2019. The animal made many $10-15 \mathrm{~km}$ round trips back and forth between

Table 3 Mean \pm standard deviation river distance $(\mathbf{k m})$ detected within the estuary from the mouth of the Shark River, Florida, USA for acoustically tagged American alligators (Alligator mississippiensis) during 2016-2018

\begin{tabular}{|c|c|c|c|c|c|c|c|}
\hline \multirow[t]{2}{*}{ Transmitter } & \multicolumn{3}{|c|}{2017 hurricane } & \multicolumn{2}{|l|}{2016} & \multicolumn{2}{|l|}{2018} \\
\hline & $\begin{array}{l}60 \text { days } \\
\text { Before }\end{array}$ & $\begin{array}{l}60 \text { days } \\
\text { After }\end{array}$ & $\begin{array}{l}4 \text { days } \\
\text { During }\end{array}$ & Before & After & Before & After \\
\hline 54252 & $24.4 \pm 0.1$ & $24.3 \pm 0.0$ & $24.3 \pm 0.0$ & $24.4 \pm 0.1$ & $24.4 \pm 0.2$ & $24.3 \pm 0.0$ & $24.3 \pm 0.0$ \\
\hline 54253 & $10.1 \pm 0.9$ & $10.8 \pm 0.3^{\mathrm{e}, \mathrm{a}}$ & $10.9 \pm 0.0^{b}$ & - & - & $10.3 \pm 0.5$ & $10.5 \pm 0.4$ \\
\hline 54254 & $10.6 \pm 3.8$ & $10.6 \pm 3.9^{e}$ & $16.1 \pm 0.8^{c}$ & - & - & $10.6 \pm 5.1$ & $9.4 \pm 4.5$ \\
\hline 54255 & $24.3 \pm 0.0$ & $24.3 \pm 0.0$ & $24.3 \pm 0.0$ & $24.4 \pm 0.2$ & $24.4 \pm 0.2$ & - & - \\
\hline 54260 & $7.9 \pm 2.2$ & $8.9 \pm 1.6^{\mathrm{e}}$ & $12.9 \pm 1.4^{\mathrm{d}}$ & $10.1 \pm 1.0$ & $9.9 \pm 1.1$ & $8.9 \pm 1.1$ & $9.8 \pm 2.0$ \\
\hline
\end{tabular}

Before and after in 2016 and 2018 correspond to the same 60-day timeframes in 2017. Some animals were not tracked these years. During the hurricane was defined as the 4-day period where environmental conditions within the estuary were rapidly changing (see [24]). All comparisons were two-sample $t$ tests with $a=0.05$

a Linear distance range across the estuary (i.e., length of river occupied) differed after the hurricane

b Too few observations during the hurricane to compare to other times

c Mean distances after were less than during the hurricane

d Mean distances before were less than during the hurricane

e Mean distances before and after the hurricane were significantly different 


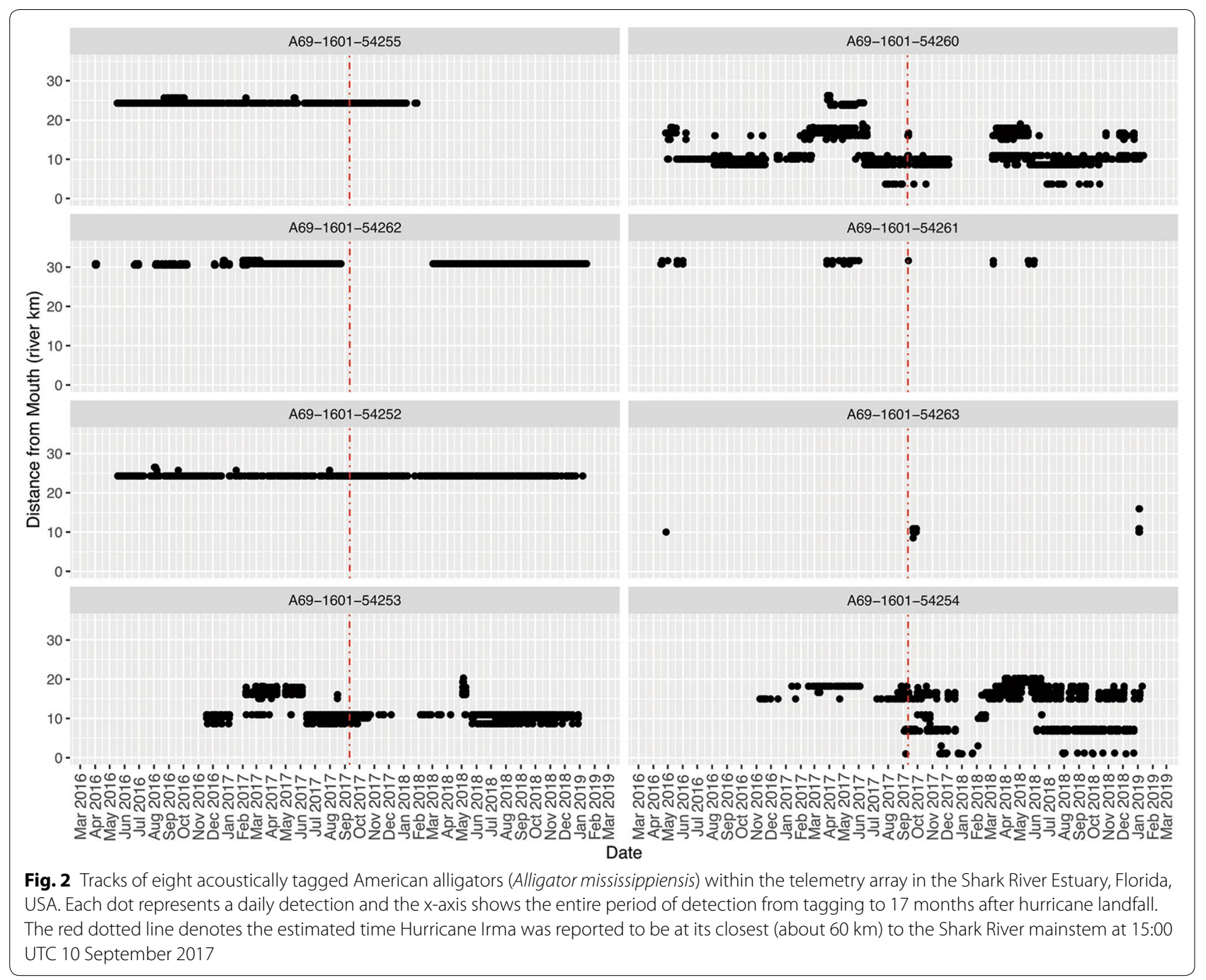

several receivers in the two habitats in February-June 2017, increasing use of Tarpon Bay upstream during the highest salinity conditions of the dry season. The animal made more short upstream excursions in August 2017 just before the hurricane in September, but ceased for over 8 months until May 2018. Even without trips upstream to Tarpon Bay from the lower river, mean river distance was higher in the $60 \mathrm{~d}$ after the hurricane than before $\left(t_{54.2}=-4.043, P<0.001\right)$. However, the animal did not change river distance in the 30-day analysis $\left(t_{25.6}=-1.480, P=0.151\right)$ or in 2018 (30 days, $t_{28.8}=0.4883, P=0.629$; 60 days, $t_{73.9}=-1.908$, $P=0.060$ ). The animal did use more of the river before compared to after the hurricane (30 days, $t_{24.1}=2.899$, $P=0.004$; 60 days, $\left.t_{55.1}=5.101, P<0.001\right)$. Linear distance ranges were the same in corresponding timeframes in 2016 (30 days, $t_{74.5}=1.312, P=0.194 ; 60$ days, $\left.t_{78.5}=0.962, P=0.339\right)$.
Animal $\times 54260$ ranged across all three broad habitats within the estuary over the course of the study, though the animal was absent from the array December 2017 to March 2018. This animal was captured on 26 April 2016 and was recaptured 13 March 2018. The acoustic tag was still transmitting and well-encased within marine epoxy. Alligator $\times 52460$ was detected at more upstream receivers after the hurricane than before (30 days, $t_{18.5}=-2.219, P=0.020 ; 60$ day, $t_{55.2}=-1.977$, $P=0.027)$. Indeed, immediately after the hurricane the animal ventured into Tarpon Bay despite spending all of its time in the 60 days before in the lower Shark River. Even though the animal spent about 4 months commuting between Tarpon Bay and Rookery Branch in Spring and Summer 2017, we did not observe the commuting behavior in the same hurricane timeframes in 2016 (30 days, $t_{17.9}=1.075, P=0.297 ; 60$ days, $t_{63.2}=0.783$, $P=0.437$ ) or in 2018 (30 days, $t_{20.2}=0.529, P=0.603$; 
60 days, $\left.t_{28.3}=-1.064, P=0.296\right)$. Mean river distance during the 4-day hurricane window was greater than before $\left(t_{2.5}=-4.678, P=0.014\right)$, but not different to after $\left(t_{1.5}=-3.519, P=0.107\right)$. Also the animal did not change linear distance ranges before and after the hurricane (30 days, $t_{10.9}=0.693, P=0.503 ; 60$ days, $t_{39.3}=1.12$, $P=0.268$ ), in the same timeframe in 2016 (30 days, $t_{24.2}=0.159, P=0.875 ; 60$ days, $\left.t_{37.5}=-0.670, P=0.507\right)$, or in 2018 (30 days, $t_{11.5}=-0.721, P=0.485 ; 60$ days, $\left.t_{21.4}=-0.300, P=0.767\right)$.

Two animals likely moved from marsh and mangrove forest habitats to river channels during and shortly after the hurricane (Fig. 2). We do not have receivers in the marsh and forest habitats, but we infer that these animals were using these habitats during their absence from the array and based on the directionality determined from our gated receivers in the river channel habitat. Both of these animals had large gaps in detections; thus, we were not able to compare before and after hurricane movements and space use. Animal $\times 54261$ had large gaps in detection throughout the study period. The animal was detected for a few hours far upstream in Rookery Branch on 12 September immediately after the hurricane. These detections were in the midst of a large gap from July 2017 to March 2018. The animal was detected moving along the transition zone where stream channels in the headwaters becomes a freshwater marsh. Animal $\times 54263$ was only detected for three short time frames on receivers in the lower river: immediately after capture in April 2016, over a week after the hurricane from 21-28 September 2017, and immediately before the last download in January 2019. Potentially, this animal was residing in the tidal mangrove forests adjacent to the Shark River channel.

Lastly, one animal exhibited major changes in movement patterns and habitat use before, during, and after Hurricane Irma (Fig. 2). Animal $\times 54254$ was exclusively detected in Tarpon Bay from its capture in November 2016 to September 2017. On 3 September 2017, the animal moved downstream more than $10 \mathrm{~km}$ and was detected in our lower Shark River receivers until 7 September including several hours of detections at river $\mathrm{km}$ 1. On 8 September 2017, the animal was detected back in Tarpon Bay, however there were no detections from 8 September until the animal was picked up again in Tarpon Bay on 11 September. On 12 September the animal made another trip downstream and remained until 20 September when regular excursions between Tarpon Bay and the coast began. This behavior persisted at least until the last download in January 2019. Due to these commuting trips, the animal was detected at more downstream receivers after the hurricane than before (30 days, $t_{30.9}=2.825, P=0.004 ; 60$ days, $t_{52.9}=3.755$, $P<0.001)$. The animal showed the same pattern in the corresponding timeframes in 2018 at the 30 days $\left(t_{38.7}=2.438, P=0.010\right)$, but not for the 60-day analysis $\left(t_{84.7}=1.117, P=0.267\right)$. Mean river distance during the 4-day hurricane window was greater than after $\left(t_{9.9}=-5.141, P<0.001\right)$, but not different to before $\left(t_{11.5}=-1.536, P=0.152\right)$. The animal did not have different linear distance ranges before and after the hurricane (30 days, $t_{24.5}=-0.659, P=0.516 ; 60$ days, $t_{52.9}=-1.533$, $P=0.131$ ) or for 2018 (30 days, $t_{31.8}=0.987, P=0.331$; 60 days, $t_{78.5}=0.962, P=0.339$ ).

\section{Discussion}

Though few studies have investigated how crocodilians respond to tropical cyclones, nearly all focus on negative effects on nesting success or passive displacement of alligators from storm surge and flooding. For instance, evidence indicates that tropical storms and hurricanes reduce nesting success and lead to hatchling mortality through flooding for both the American alligator and the American crocodile (Crocodylus acutus) [8, 21, 28, 30]. Contrary to many large-bodied animals, mortality rates via telemetry are difficult to obtain for crocodilians given that some individuals exhibit largely sedentary movement patterns [10, 34]. Nonetheless, we did not observe any indication of direct storm-related mortality typically signified by constant hourly detections at one station for an extended time. This is in contrast to apparent hurricane-related mortality events found in other large estuarine predators within Shark River Estuary, including juvenile bull sharks [36] and common snook [24] during Hurricane Irma. Given the ability of adult alligators to seek shelter on both land and water and their large and armored bodies, a major hurricane may be unlikely to cause mass direct mortalities of adult alligators.

Everglades alligators are thought to be in poor condition relative to other parts of their range due to harsh environmental conditions (e.g., anthropogenic disturbance in water levels, high temperatures, etc.) $[3,11,16]$. We recorded four of eight alligators as having poor body condition at capture; the other four had good $(n=3)$ or excellent $(n=1)$ body condition. We predicted that individuals with higher condition were more likely to exhibit a strong movement response due to the availability of energy stores to undertake a journey. However, observed body condition at capture was not correlated with behavioral response to the hurricane. Our small sample size, the complexity of the relationship between body condition and dispersal (see [2]), and that alligators are capable of long periods of time ( $>6$ months) without eating [20] may have limited our ability to detect a difference. In addition, it is likely that body condition changed over the months to over a year passing since capture to the hurricane strike. 
Alligators need regular access to low-salinity water for survival due to their lack of functioning salt glands and are physiologically limited in their distribution within coastal estuaries $[12,23]$. Nonetheless, alligators in the Shark River Estuary exhibit considerable individual variation in movement behavior across the estuary and use several movement tactics including being residents of a particular habitat and exhibiting two forms of commuting: (1) making short trips from the mid-estuarine zone to freshwater areas and (2) undergoing regular but relatively brief long-distance travels downstream to exploit prey-rich marine food webs [33]. We observed each of these tactics within our subset of tracked animals. Four alligators remained in the upstream freshwater areas and marsh exclusively. One animal ranged across most of the estuary and two individuals used mid-estuary habitats and made regular long-distance trips to downstream areas. Lastly, we had one individual that shifted its behavior from remaining upstream exclusively to exhibiting commuting behavior to downstream foraging areas after the storm in September 2017 to our last download in January 2019. Our data indicate that the timing of the hurricane correlated with a shift from resident to commuter movement tactics for this animal. Within our Shark River Estuary population, there is considerable consistency in movement behaviors across years and no other alligator has been observed to switch general movement tactics $[33,34]$.

We saw variation in movement responses to Hurricane Irma by our tracked alligators, but two animals showed no discernable change in movements or habitat use throughout the study. The remaining six animals may have altered movement patterns or habitat use as a result of the hurricane. For instance, one animal remained slightly more upstream, used less of the estuary, and halted excursions to Tarpon Bay from mid-estuary for 8 months after the hurricane, which had been regular trips pre-hurricane. Another animal appeared to stop regular short trips upstream within Rookery Branch after the hurricane. Also, a different animal moved upstream from the lower river to Tarpon Bay immediately after the hurricane despite not doing this in the $60 \mathrm{~d}$ prior. It is possible that these changes were not related to the hurricane. Environmental conditions (e.g., dissolved oxygen and salinity regimes) remained altered for weeks after Hurricane Irma within the estuary [36] and could have changed the need for alligators to travel for food, thermoregulation, or osmoregulation. Two other alligators appeared to have moved from marsh and mangrove forest habitats to river channels soon after ( 2 days and 11 days) the hurricane strike. These findings mimic those of Chabreck
[7], who observed alligators moving from marsh habitats to open water habitats like canals and bayous after Hurricane Carla in 1961. Seeking deeper water habitats to deal with increasing discharge, wave action, or rising water levels that follow tropical cyclones has been documented for several aquatic taxa [19, 24, 36]. Given that alligators are semi-aquatic air-breathing animals, it is unlikely that their response is one of seeking refuge from expected future disturbances. It is possible that these movements into river channels were not related to the hurricane, but we suspect that prey or carrion from the marsh and mangrove forest may have moved or been washed into the river channels from high inflow [14], with alligators responding to changes in food distribution.

Lastly, one animal shifted to commuting downstream from its upstream habitat after the storm. We were regularly detecting the animal in Tarpon Bay until the animal made its trip downstream 7 days before Irma's strike. We did not detect the animal during the storm but picked it up less than 2 days later on a downstream receiver. We do know that diverse taxa including bats, birds, elasmobranchs, and teleosts can detect declining barometric pressure that comes days before storms [4, 17, 29, 37]. However, it is difficult to know if animals are sensitive enough to predict changes 1 week out from a major storm. The commuting behavior we observed from this animal could be a response to increased prey availability downstream shortly before and after the storm. In anticipation of and after the hurricane, estuarine and freshwater fish may have actively or passively moved downstream due to high inflow and lowered salinities [14, 36]. Favorable foraging opportunities during this time also explain why the animal traveled back upstream during the dry season when the downstream areas become too high in salinity for alligators [33]. Increasing inflow of freshwater from upstream rainfall and reduced salinities seen after Hurricane Irma [36] potentially increased the accessibility of downstream habitats and decreased osmoregulatory costs of movements compared to times of higher salinities [12]. Similar to the behavior observed for this alligator, another study found that acoustically tracked juvenile bull sharks returning to Shark River Estuary after Hurricane Irma shifted their habitat use towards downstream areas [36]. The tracked alligator continued this commuting behavior throughout the wet seasons of 2017 and 2018 during the study period. This behavior is supported by another study showing that most downstream trips occur during the wet season (JulyDecember) when salinities are low and prey availability is higher [33]. 


\section{Conclusions}

Alligators are important predators in many estuarine ecosystems throughout the southeastern United States [25]. Though we had limited sample sizes, our research gave us insight into alligator movement behaviors in the context of a major hurricane disturbance. We found considerable variability in alligator movement behaviors following a hurricane, ranging from no discernable changes in movements to one animal exhibiting a complete shift in movement tactics not previously observed in long-term tracking data of this population. Understanding aspects of an animal's behavior and ecology can provide insight into how future extreme weather events might impact populations and individual ecological roles. With predicted changes in the frequency and intensity of extreme weather [18], studies evaluating how animals respond to these events may be necessary for effective ecosystem management.

\section{Abbreviations}

USA: United States of America; cm: Centimeter; kg: Kilogram; UTC: Coordinated universal time; PVC: Polyvinyl chloride; K: Fulton's body condition factor; M: Body weight; SD: Standard deviation; d: Day(s).

\section{Acknowledgements}

We are grateful to many field and lab volunteers who assisted with capture and sample processing. Adam Rosenblatt's pioneering work directed the line of investigation for this project. Katherine Strickland assisted with designing the graphics. BAS was supported by University Graduate School and Department of Biological Sciences assistantships at Florida International University as well as an Everglades Foundation fellowship. This is a contribution from the Center for Coastal Oceans Research in the Institute for Water and Environment at Florida International University.

\section{Authors' contributions}

$B A S, M R H, J A M, J S R$, and KG developed the questions investigated within the study. MRH, FJM, KG, BAS, JAM, NV, and JSR designed the sampling protocol. $B A S, K G, J A M, N V, V P$, and FJM conducted the fieldwork and collected the data. BAS analyzed the data. BAS, KG, FJM, JAM, NV, VP, JSR, and MRH interpreted the data and wrote the manuscript. All authors read and approved the final manuscript.

\section{Funding}

This work was supported by the National Science Foundation through the Florida Coastal Everglades Long-Term Ecological Research program under Grant DEB-1237517 and in collaboration with the RECOVER program of the Comprehensive Everglades Restoration Plan.

\section{Availability of data and materials}

Datasets used for analysis within this study are available upon request through the FCE LTER website: http://fce.Iternet.edu/or through the corresponding author.

\section{Ethics approval and consent to participate}

Research and animal procedures were conducted under the auspices of protocol \#IACUC-15-044-CR01 from the Institutional Animal Care and Use Committee of Florida International University and in accordance with sampling permits \#EVER-2015-SCI-0036 and \#EVER-2017-SCI-0031 granted by Everglades National Park.

\section{Consent for publication}

Not applicable.

\section{Competing interests}

The authors declare that they have no competing interests.

\section{Author details}

${ }^{1}$ Department of Biological Sciences, Florida International University, Miami, FL 33199, USA. ${ }^{2}$ Ft. Lauderdale Research and Education Center, University of Florida, Davie, FL 33314, USA. ${ }^{3}$ Department of Earth and Environment,

Florida International University, Miami, FL 33199, USA.

Received: 20 September 2019 Accepted: 6 February 2020

Published online: 24 February 2020

\section{References}

1. Bailey H, Secor DH. Coastal evacuations by fish during extreme weather events. Nature. 2016;6:30280.

2. Baines CB, McCauley SJ, Rowe L. Dispersal depends on body condition and predation risk in the semi-aquatic insect, Notonecta undulata. Ecol Evol. 2015;5(12):2307-16.

3. Brandt LA, Beauchamp JS, Jeffery BM, Cherkiss MS, Mazzotti FJ. Fluctuating water depths affect American alligator body condition in the Everglades, Florida USA. Ecol Ind. 2016;67:441-50.

4. Breuner CW, Spraque RS, Patterson SH, Woods HA. Environment, behavior, and physiology: do birds use barometric pressure to predict storms? J Exp Biol. 1982;216:1982-90.

5. Cangialosi JP, Latto AS, Berg RJ. 2018. Hurricane Irma (AL112017). Tropical Cyclone Report: National Hurricane Center. https://www.nhc.noaa.gov/ data/tcr/AL112017_Irma.pdf. Accessed 13 Sept 2018.

6. Chabreck $\mathrm{RH}$. Methods of capturing, marking, and sexing alligators. Proceedings of the Southeastern Association of Game and Fish Commissioners. 196;17;47-50

7. Chabreck RH. The movement of alligators in Louisiana. Proceedings of the Southeastern Association of Game and Fish Commissioners. 1965 19;102-110

8. Charruau P, Thorbjarnarson JB, Henaut Y. Tropical cyclones and reproductive ecology of Crocodylus acutus on a Caribbean atoll in Mexico. J Nat Hist. 2010;44(11-12):741-61.

9. Childers DL. A synthesis of long-term research by the Florida Coastal Everglades LTER Program. Hydrobiologia. 2006;569:531-44.

10. Coulson R, Hernandez T. Biochemistry of the Alligator. Baton Rouge: Louisiana State University Press; 1964.

11. Dalrymple GH. Growth of American alligators in the Shark Valley region of Everglades National Park. Copeia. 1996;1996:212-6.

12. Dunson W, Mazzotti FJ. Salinity as a limiting factor in the distribution of reptiles in Florida Bay: a theory for the estuarine origin of marine snakes and turtles. Bull Mar Sci. 1989;44:229-44.

13. Elsey RM, Aldrich C. Long-distance displacement of a juvenile alligator by Hurricane Ike. Southeast Nat. 2009;8(4):746-9.

14. Flannery MS, Peebles EB, Montgomery RT. A percent-of-flow approach for managing reductions of freshwater inflows from unimpounded rivers to southwest Florida estuaries. Estuaries. 2002;25:1318-32. https://doi. org/10.1007/BF02692227.

15. Fujisaki I, Hart KM, Mazzotti FJ, Cherkiss MS, Sartain AR, Jeffery BM, Beauchamp JS, Denton M. Home range and movements of American alligators (Alligator mississippiensis) in an estuary habitat. Anim Biotelemetry. 2014;2(8):1-10.

16. Fujisaki I, Rice KG, Pearlstine LG, Mazzotti FJ. Relationship between body condition of American alligators and water depth in the Everglades, Florida. Hydrobiologia. 2009;635:329-38.

17. Grammer PO, Mickle PF, Peterson MS, Havrylkoff JM, SlackWT, Leaf RT. Activity patterns of Gulf Sturgeon (Acipenser oxyrinchus desotoi) in the staging area of the Pascagoula river during fall outmigration. Ecol Freshw Fish. 2015;24:553-61.

18. Hegerl GC, Hanlon H, Beierkuhnlein C. Climate science: elusive extremes. Nat Geosci. 2011:4:142-3.

19. Jury SH, Howell WH, Watson WH. Lobster movements in response to a hurricane. Mar Ecol Prog Ser. 1995:119:305-10.

20. Lance VA. Alligator physiology and life history: the importance of temperature. Exp Gerontol. 2003;38(7):801-5. 
21. Lance VA, Elsey RM, Butterstein G, Trosclair PL, Merchant M. The effects of Hurricane Rita and subsequent drought on alligators in southwest Louisiana. J Exp Zool. 2010;313A:106-13.

22. Lance VA, Elsey RM, Trosclair PL III, Nunez A. Long-distance movement by American alligators in southwest Louisiana. Southeast Nat. 2011;10(3):389-98.

23. Lauren D. The effect of chronic saline exposure on the electrolyte balance, nitrogen metabolism, and corticosterone titer in the American alligator, Alligator mississippiensis. Comp Biochem Physiol. 1985;81A:217-23.

24. Massie JA, Strickland BA, Santos R, Hernandez J, Viadero N, Boucek RE, Willoughby $H$, Heithaus MR, Rehage JS. Going downriver: patterns and cues in hurricane-driven movements of common snook in a coastal river. Estuar Coasts. 2019. https://doi.org/10.1007/s12237-019-00617-y.

25. Mazzotti FJ, Brandt LA. Ecology of the American alligator in a seasonally fluctuating environment. In: Davis SM, Ogden JC, editors. Everglades: The ecosystem, its restoration. St: Lucie Press, Delray Beach, FL; 1994. p. 485-505.

26. Mazzotti FJ, Best GR, Brandt LA, Cherkiss MS, Jeffery BM, Rice KG. Alligators and crocodiles as indicators for restoration of Everglades ecosystems. Ecol Ind. 2009:9:S137-49.

27. Michener WK, Blood ER, Bildstein KL, Brinson MM, Gardner LR. Climate change, hurricanes, and tropical storms, and rising sea level in coastal wetlands. Ecol Appl. 1997;7(3):770-801.

28. Ogden JC. Status and nesting biology of the American crocodile in Florida. J Herpetol. 1978;12(2):183-96.

29. Paige KN. Bats and barometric pressure-conserving limited energy and tracking insects from the roost. Funct Ecol. 1995;9:463-7.

30. Pimm SL, Davis GE, Loope L, Roman CT, Smith TJ, Tilmant JT. Hurricane Andrew. Bioscience. 1994:44(4):224-9.
31. Pruitt JN, Little AG, Majumdar SJ, Schoener TW, Fisher DN. Call-to-action: a global consortium from tropical cyclone ecology. Trends Ecol Evol. 2019:34(7):588-90

32. Romigh MM, Davis SE, Rivera-Monroy VH, Twilley RR. Flux of organic carbon in a riverine mangrove wetland in the Florida coastal Everglades. Hydrobiologia. 2006;569:505-16.

33. Rosenblatt $A E$, Heithaus MR. Does variation in movement tactics and trophic interactions among American alligators create habitat linkages? J Anim Ecol. 2011:80:786-98.

34. Rosenblatt AE, Heithaus MR, Mazzotti FJ, Cherkiss M, Jeffery BM. Intrapopulation variation in activity ranges, diel patterns, movement rates, and habitat use of American alligators in a subtropical estuary. Estuar Coast Shelf Sci. 2013;135:182-90.

35. Rudnick DT, Chen Z, Childers DL, Fontaine TD. Phosphorus and nitrogen inputs to Florida Bay: the importance of the Everglades watershed. Estuaries. 1999:22:398-416.

36. Strickland BA, Massie AJ, Viadero N, Santos R, Gastrich KR, Paz V, O'Donnel P, Kroetz AM, Ho DT, Rehage JS, Heithaus MR. Movements of juvenile bull sharks in response to a major hurricane within a tropical estuarine nursery area. Estuar Coasts. 2019. https://doi.org/10.1007/s12237-019-00600 $-7$.

37. Udyawer V, Chin A, Knip DM, Simpfendorfer CA, Heupel MR. Variable response of coastal sharks to severe tropical storms: environmental cues and changes in space use. Mar Ecol Prog Ser. 2013;480:171-83.

\section{Publisher's Note}

Springer Nature remains neutral with regard to jurisdictional claims in published maps and institutional affiliations.
Ready to submit your research? Choose BMC and benefit from:

- fast, convenient online submission

- thorough peer review by experienced researchers in your field

- rapid publication on acceptance

- support for research data, including large and complex data types

- gold Open Access which fosters wider collaboration and increased citations

- maximum visibility for your research: over $100 \mathrm{M}$ website views per year

At $\mathrm{BMC}$, research is always in progress.

Learn more biomedcentral.com/submissions 